\title{
Functional Properties of Chia Seed Mucilage Supplemented In Low Fat Yoghurt
}

\author{
Amira M.G. Darwish ${ }^{1}$, Randa E. Khalifa ${ }^{2}$, Sobhy A. El Sohaimy ${ }^{1}$
}

\begin{abstract}
Modern diet lifestyle demands of healthy natural foods represent a challenge for food manufacturers to lead towards the healthy new trends. This work aimed to study the microstructure of chia seed (Salvia hispanica L.) and its mucilage, provide chemical and functional properties of mucilage before supplementation in low-fat yoghurts and evaluate its impact on products' composition, texture, and acceptance. The micro morphology of chia seed and its mucilage were described via scanning electron microscope (SEM). For physical functional properties evaluation; functional groups were studied using Fourier Transform Infrared (FTIR) spectroscopy; the thermal behavior was analyzed using Thermogravimetric Analyzer (TGA), and Water/ Oil Holding capacities (WHC/ OHC) were assessed. The gross chemical composition of mucilage was studied before supplementation with various concentrations $(1,1.5$ and $2 \%$ ) at different ratios of fat content (1, 2 and $3 \%$ ) yoghurts, monitoring mucilage effect on chemical, rheological (using Texture Analyzer) and organoleptic properties of yoghurts. Chia mucilage micrographs showed fine fibrous network structure supported by high fiber, protein, ash and fat values $(12.4,10.68,9.64$, and $3.10 \%$ respectively). The FTIR analysis indicated the presence of uronic acids, mannose, carboxylic acid, pyranose, glucopyranose, xylopyranose groups in mucilage polysaccharides, which influenced its thermal stability. Mucilage showed comparable high WHC/OHC values (5.25g water, $5.85 \mathrm{~g}$ oil/ $\mathrm{g}$ sample) that nominate it to perform as a stabilizer and emulsifier. Along with increased chia mucilage concentrations in fortified yoghurt, fiber content elevation subsequently reflected on higher values of springiness, and descendant hardness values that produced "soft" yoghurts as described in sensory evaluation.
\end{abstract}

Key words: FTIR; Microstructure; SEM; Texture analysis; TGA.

\section{INTRODUCTION}

Chia seeds have been widely applied in food applications such as yoghurt, cereals, juices or cakes in different countries all over the world including New Zealand, Canada, Chile, Mexico, Australia and USA (Ali et al., 2012). Due to unique properties of forming a gelatinous mass when soaked in water due to the presence of high amount of mucilage and gums, chia can be employed in the food industry targeting better texture and stabilization. The mucilage lays in the three first layers of the seed coat and mucilage fibers start to be visible when full hydrated, and it is exceptionally rich especially in polysaccharides (71.22\%) (Muñoz et al., 2012). Therefore, chia and its mucilage be friendly for the gut health because soluble fiber prolongs the gastrointestinal transit time that aids in improved digestion which consequently related to gradual increase in postprandial blood glucose levels and decrease in insulin resistance over a period of time (Suri et al., 2016).

Low fat ratios are highly recommended in food production since this may aid in reduced risk of many syndromes such as cardiovascular disease (CVD), hepatic steatosis, and obesity (Felisberto et al., 2015). Fat replacers consist of lipid-, protein-, or carbohydrate-based ingredients replaced with fat in low fat food products. Food hydrocolloids are added to food systems mainly to modify rheological properties, increase the stability, or reduce calories. Several previous trials were carried out on yoghurt fortification applying plant-based mucilage such as, okra fruits, quince seed and psyllium seed (Hussein et al., 2011; Khalifa et al., 2011; Nikoofar et al., 2013).

So, the objective of the current work was to study microstructure of chia seed (Salvia hispanica L.) and its mucilage, provide gross chemical composition, characterization of physical and functional properties of chia seed mucilage before supplementation in low fat yoghurt and evaluate the effect of this fortification on product composition, texture profile and consumer acceptance. This would provide useful information contributing industrial innovative applications of chia seed mucilage as reach natural fat mimetic, thickening and gelling agent.

\section{MATERIALS AND METHODS}

\section{Materials}

Organic dark chia seeds (Salvia hispanica L.) (Hunter Foods Group Limited BVI, U.K.), was purchased from local market Dubai, United Arab of

${ }^{1}$ Food Technology Dept., Arid Lands Cultivation Research Institute (ALCRI), City of Scientific Research and Technological Applications (SRTA-City), Alexandria, Egypt

${ }^{2}$ Polymer Materials Research Department, Advanced Technology and New Materials Research Institute (ATNMRI), City of Scientific Research and Technological Applications (SRTA-City), Alexandria, Egypt Received June 11, 2018, Accepted September 13, 2018 
Emirates. Milli-Q water was used in all the experiments (Siemens Ultra Clear Water Purification Systems, Series 2000). Corn oil purchased from a local store and stored at room temperature. For application, pasteurized skimmed milk (8.5\% SNF), cream (25\% fat) and skimmed milk powder (SMP) were obtained from the local market. Yoghurt commercial starter culture YoMix 495 (Streptococcus thermophilus and Lactobacillus delbrueckii subsp. bulgaricus) was obtained from Danisco Egypt.

\section{Chia mucilage extraction}

Chia mucilage extraction was performed according to the method proposed by (Avila-de la Rosa et al., 2015) with some modifications. A sample of $40 \mathrm{~g}$ of whole chia seeds was placed in a $1 \mathrm{~L}$ beaker and warm Milli-Q water was added at ratio $(1: 20 \mathrm{w} / \mathrm{v})$, stirred with a magnetic stirrer for $3 \mathrm{~h}$ at a constant temperature of $60^{\circ} \mathrm{C}$. The mucilage was separated from the seeds by high speed centrifuge (Pro-Centrifuge, Centurion Science Limited, UK) for $20 \mathrm{~min}$ at $3382 \mathrm{xg}$, and then lyophilized via vacuum freeze-dryer (Model FDF 0350, Korea), stored at $-80^{\circ} \mathrm{C}$ for characterization.

Microstructural and functional characterization of chia seed and its mucilage

\section{Scanning electron microscope}

The surface morphology of whole seeds, seeds powder, and freeze-dried mucilage (M1) was analyzed using a scanning electron microscopy (SEM- Joel Jsm 6360LA, Japan). The fracture surfaces were vacuum coated with gold for scanning electron microscope (Munir et al., 2016).

\section{Fourier transform infrared (FTIR) spectroscopy}

The FTIR spectra of whole seeds, seeds powder and freeze-dried mucilage were acquired by using a Fourier transform infrared spectroscopy (Shimadzu FTIR-8400 S, Japan) equipped with (ATR 8000A) in the spectral range of $4000-400 \mathrm{~cm}^{-1}$ (Cerqueira et al., 2011).

\section{Thermogravimetric analysis (TGA)}

Thermal characteristics of whole seeds, seeds powder, and freeze-dried mucilage during the heating process were monitored using a thermogravimetric analyzer (Shimadzu TGA-50, Japan). All individuals were heated at a rate of $20^{\circ} \mathrm{C} / \mathrm{min}$ under flow of $\mathrm{N} 2$ up to $800{ }^{\circ} \mathrm{C}$ (Cerqueira et al., 2011).

\section{Water-Holding (WHC) and Oil-Holding Capacity (OHC)}

The WHC/ OHC were determined as described by (Alfredo et al., 2009). Briefly, $0.1 \mathrm{~g}$ of whole chia seeds, powdered chia seeds or freeze-dried mucilage was stirred into $20 \mathrm{~mL}$ of Milli-Q water or corn oil for two minutes at room temperature. The resultant suspensions were centrifuged at $699 \mathrm{xg}$ for $30 \mathrm{~min}$ (Pro-Centrifuge, Centurion Science Limited, UK), the supernatant volume was measured. Water-holding capacity was expressed as $\mathrm{g}$ of water/ $\mathrm{g}$ sample, and oil-holding capacity was expressed as $g$ of oil held/ $g$ sample.

\section{Chia yoghurt application}

\section{Chia yoghurt preparation}

Pasteurized milk (8.5\% SNF) was standardized using SMP to reach (14\% SNF), divided into three portions to adjust fat content up to 1,2 and $3 \%$ fat using cream (25\% fat), wormed to $42^{\circ} \mathrm{C}$, and then inoculated with 1$2 \%$ of common yoghurt culture Yo-Mix 495. Counting on a preliminary experiment, the standardized inoculated milk was replaced with $(20 \%)$ chia mucilage dispersions with concentrations (1, 1.5 and 2\%), and then distributed into cups. The cups were incubated at $42^{\circ} \mathrm{C}$ until set coagulation (about $4 \mathrm{~h}$ ), and then cooled and stored at $4^{\circ} \mathrm{C}$. The yoghurt making and applied calculations using Pearson's square were performed as described by Tamime and Robinson (1999). The chia yoghurt formulations and replacements of chia seeds mucilage dispersions are shown in Table (1).

\section{Gross chemical composition of chia seed mucilage and chia yoghurt}

The gross chemical composition analysis of chia freeze-dried mucilage and chia yoghurts was determined according to AOAC (1990). Crude fiber content was determined using Crude Fiber Analysis in Feeds - Filter Bag Technique A2000 - AOCS Approved Procedure Ba 6a-05 (Ankom Technology Corp., Macedon, NY).

\section{Texture profile analysis (TPA)}

Textural properties of chia yoghurt were evaluated using a texture analyzer (TA1000, Lab Pro (FTC TMSPro), USA). Samples were tested in their cups using Perspex cone $\mathrm{P} / 45 \mathrm{C}$, samples were allowed to stand at ambient temperature for at least $1 \mathrm{~h}$ before testing. A two-bite penetration test was performed and operated at a crosshead speed $50 \mathrm{~mm} / \mathrm{sec}$. Hardness, adhesiveness, cohesiveness, springiness and gumminess were evaluated as described by Bourne (2002) and Szczesniak et al., (1963).

\section{Sensory evaluation}

Ten staff members, ( 8 men and 2 women, aged between 27 to 51 years), performed sensory evaluation on fresh chia yoghurt samples at Food Technology Dept., Arid Lands Cultivation Research Institute, SRTA-City, Alexandria, Egypt. The criterion for selection depended on their experience and background related to yoghurt products. The samples were allowed to rest at room temperature $\left(25^{\circ} \mathrm{C}\right), 10 \mathrm{~min}$ before evaluation. Panelists were instructed to evaluate the chia yoghurt with respect to their degree of acceptance as follows; smell and taste 
Table 1. Gross chemical composition of lyophilized chia mucilage and different formulations of chia yoghurt

\begin{tabular}{|c|c|c|c|c|c|c|c|c|c|c|c|}
\hline \multirow{2}{*}{ Sample } & \multicolumn{2}{|c|}{ Formulations } & \multicolumn{9}{|c|}{ Proximate analysis } \\
\hline & Fat $\%$ & Mucilage \% & Fat $\%$ & Protein \% & Fiber $\%$ & Ash\% & TS\% & pH & TA\% & SNF\% & F/DM\% \\
\hline Chia mucilage & - & - & 3.10 & 10.68 & 12.47 & 9.64 & 89.35 & 6.41 & ND & ND & ND \\
\hline \multicolumn{12}{|l|}{ Chia yoghurt } \\
\hline T1 (Control1) & 1 & 0 & $1.09^{\mathrm{a}}$ & $3.34^{\mathrm{a}}$ & $0.01^{\mathrm{b}}$ & $6.98^{\mathrm{a}}$ & $12.30^{\mathrm{b}}$ & $4.71^{\mathrm{a}}$ & $0.63^{\mathrm{a}}$ & $11.21^{\mathrm{b}}$ & $8.87^{\mathrm{a}}$ \\
\hline $\mathrm{T} 2$ & 1 & 1 & $1.05^{\mathrm{a}}$ & $3.23^{\mathrm{a}}$ & $1.02^{\mathrm{a}}$ & $6.85^{\mathrm{a}}$ & $12.06^{\mathrm{b}}$ & $4.47^{\mathrm{a}}$ & $0.72^{\mathrm{a}}$ & $11.01^{\mathrm{b}}$ & $8.69^{\mathrm{a}}$ \\
\hline $\mathrm{T} 3$ & 1 & 1.5 & $1.10^{\mathrm{a}}$ & $3.20^{\mathrm{a}}$ & $1.12^{\mathrm{a}}$ & $6.80^{\mathrm{a}}$ & $13.26^{\mathrm{a}}$ & $4.45^{\mathrm{a}}$ & $0.75^{\mathrm{a}}$ & $12.16^{\mathrm{a}}$ & $8.30^{\mathrm{b}}$ \\
\hline $\mathrm{T} 4$ & 1 & 2 & $1.07^{\mathrm{a}}$ & $3.21^{\mathrm{a}}$ & $1.40^{\mathrm{a}}$ & $7.00^{\mathrm{a}}$ & $13.09^{\mathrm{a}}$ & $4.43^{\mathrm{a}}$ & $0.76^{\mathrm{a}}$ & $12.02^{\mathrm{s}}$ & $8.20^{\mathrm{b}}$ \\
\hline T5 (Control2) & 2 & 0 & $2.03^{\mathrm{a}}$ & $3.33^{\mathrm{a}}$ & $0.00^{\mathrm{b}}$ & $6.82^{\mathrm{a}}$ & $12.26^{\mathrm{b}}$ & $4.62^{\mathrm{a}}$ & $0.65^{\mathrm{a}}$ & $10.23^{b}$ & $16.53^{\mathrm{a}}$ \\
\hline $\mathrm{T} 6$ & 2 & 1 & $2.07^{\mathrm{a}}$ & $3.24^{\mathrm{a}}$ & $1.16^{\mathrm{a}}$ & $6.85^{\mathrm{a}}$ & $13.10^{\mathrm{a}}$ & $4.48^{\mathrm{a}}$ & $0.71^{\mathrm{a}}$ & $11.04^{\mathrm{a}}$ & $15.76^{\mathrm{b}}$ \\
\hline $\mathrm{T} 7$ & 2 & 1.5 & $2.08^{\mathrm{a}}$ & $3.27^{\mathrm{a}}$ & $1.19^{\mathrm{a}}$ & $6.91^{\mathrm{a}}$ & $13.39^{\mathrm{a}}$ & $4.49^{\mathrm{a}}$ & $0.71^{\mathrm{a}}$ & $11.32^{\mathrm{a}}$ & $15.50^{\mathrm{b}}$ \\
\hline $\mathrm{T} 8$ & 2 & 2 & $2.06^{\mathrm{a}}$ & $3.27^{\mathrm{a}}$ & $1.42^{\mathrm{a}}$ & $6.72^{\mathrm{a}}$ & $13.01^{\mathrm{a}}$ & $4.46^{\mathrm{a}}$ & $0.72^{\mathrm{a}}$ & $10.95^{\mathrm{a}}$ & $15.81^{\mathrm{b}}$ \\
\hline T9 (Control3) & 3 & 0 & $3.11^{\mathrm{a}}$ & $3.30^{\mathrm{a}}$ & $0.01^{\mathrm{b}}$ & $6.59^{\mathrm{ab}}$ & $13.95^{\mathrm{ab}}$ & $4.52^{\mathrm{a}}$ & $0.67^{\mathrm{a}}$ & $10.84^{\mathrm{ab}}$ & $22.28^{\mathrm{a}}$ \\
\hline $\mathrm{T} 10$ & 3 & 1 & $3.03^{\mathrm{a}}$ & $3.24^{\mathrm{a}}$ & $1.04^{\mathrm{a}}$ & $6.76^{\mathrm{a}}$ & $13.73^{\mathrm{b}}$ & $4.50^{\mathrm{a}}$ & $0.68^{\mathrm{a}}$ & $10.70^{\mathrm{b}}$ & $22.07^{\mathrm{ab}}$ \\
\hline $\mathrm{T} 11$ & 3 & 1.5 & $3.09^{\mathrm{a}}$ & $3.23^{\mathrm{a}}$ & $1.30^{\mathrm{a}}$ & $6.47^{\mathrm{ab}}$ & $14.18^{\mathrm{a}}$ & $4.47^{\mathrm{a}}$ & $0.68^{\mathrm{a}}$ & $11.09^{\mathrm{ab}}$ & $21.77^{b c}$ \\
\hline $\mathrm{T} 12$ & 3 & 2 & $3.04^{\mathrm{a}}$ & $3.22^{\mathrm{a}}$ & $1.37^{\mathrm{a}}$ & $6.33^{\mathrm{b}}$ & $14.16^{\mathrm{a}}$ & $4.44^{\mathrm{a}}$ & $0.70^{\mathrm{a}}$ & $11.13^{\mathrm{a}}$ & $21.44^{\mathrm{c}}$ \\
\hline
\end{tabular}

Results represent the means of duplicates

a,b,c,.. Means values in the same column (of each control group) marked with unlike letters are significantly different $(\mathrm{p}<0.05)$

(1-4), body and texture (1-2), and appearance (1-4). The sensory evaluation procedure was modified from the method described by Allam et al., (2017). The average was calculated.

\section{Statistical analysis}

Statistical analyses were performed using Analytical Software SPSS ${ }^{\circledR} 13.0$ (Statistical Package for the Social Sciences) (2005). Differences were considered significant at $p<0.05$.

\section{RESULTS AND DISCUSSION}

\section{Morphological and Microstructure of chia seed and its mucilage}

Figures (1 and 2) show SEM micrograph of chia seed and its freeze-dried mucilage. Fig (1. A) shows the whole seed, that facilitated the seed size calculation from SEM microscopy which was $2.01 \pm 0.07 \mathrm{~mm}$ length, $1.15 \pm 0.03 \mathrm{~mm}$ width, and $0.72 \pm 0.02 \mathrm{~mm}$ thickness. These dimensions agreed with those reported by (Capitani et al., 2013). Regarding seed structure, Fig. (1. B) showed seed longitudinal section marking, pericarp, testa (seed coat) and endosperm. For more details, Fig. (1. C) of pericarp longitudinal section showing that after cuticle, the seed consists of three layers of cells, exocarp, mesocarp, and endocarp (inner epidemis). In addition, it can be observed that, the latter layer (epidemis) constituting approximately $80 \%$ of the seed, and formed of rough surface cells with an irregular geometric shape arranged in a grid, which is responsible of producing large quantities of mucilage, by the rupture of the outer cell wall when they are wet, as reported by Salgado-Cruz et al., (2013).

Figure (2) shows SEM micrograph of chia seed freeze-dried mucilage with different magnifications. These micrographs show fine fibrous structure of freezedried mucilage with overlapped sheets in the least magnification $(500 \mu \mathrm{m}, \mathrm{X} 30$ at $10 \mathrm{KV})$, which could be related to the least degradation during lyophilizing process that resulted in fine network structure. Similar observation about molecular structure of freeze-dried natural biopolymers originated from plants was reported by Mirhosseini and Amid (2012), in addition to better performance of functional properties such as foaming capacity and gel formation among differently dried seed gums.

\section{Fourier transform infrared spectroscopy (FTIR)}

Figure (3) shows micrographs of seeds powder, whole chia seeds, and chia mucilage IR spectra, to facilitate marking changes in functional groups with water extraction. As expected, the chia seed and chia powder exhibited identical spectra, while chia mucilage showed less bands in the region between, 1700 and 1000 $\mathrm{cm}^{-1}$ that represent only soluble amides (proteins) and polysaccharides (fibers) functional groups. Some plant mucilage was reported to be hydrocolloids of a complex polymeric substances of carbohydrate nature with branched structure of polar glycoprotein and exopolysaccharides (Oladoja et al., 2017). Referring to gross chemical composition of chia mucilage represented in (Table 1), the mucilage main constituents 


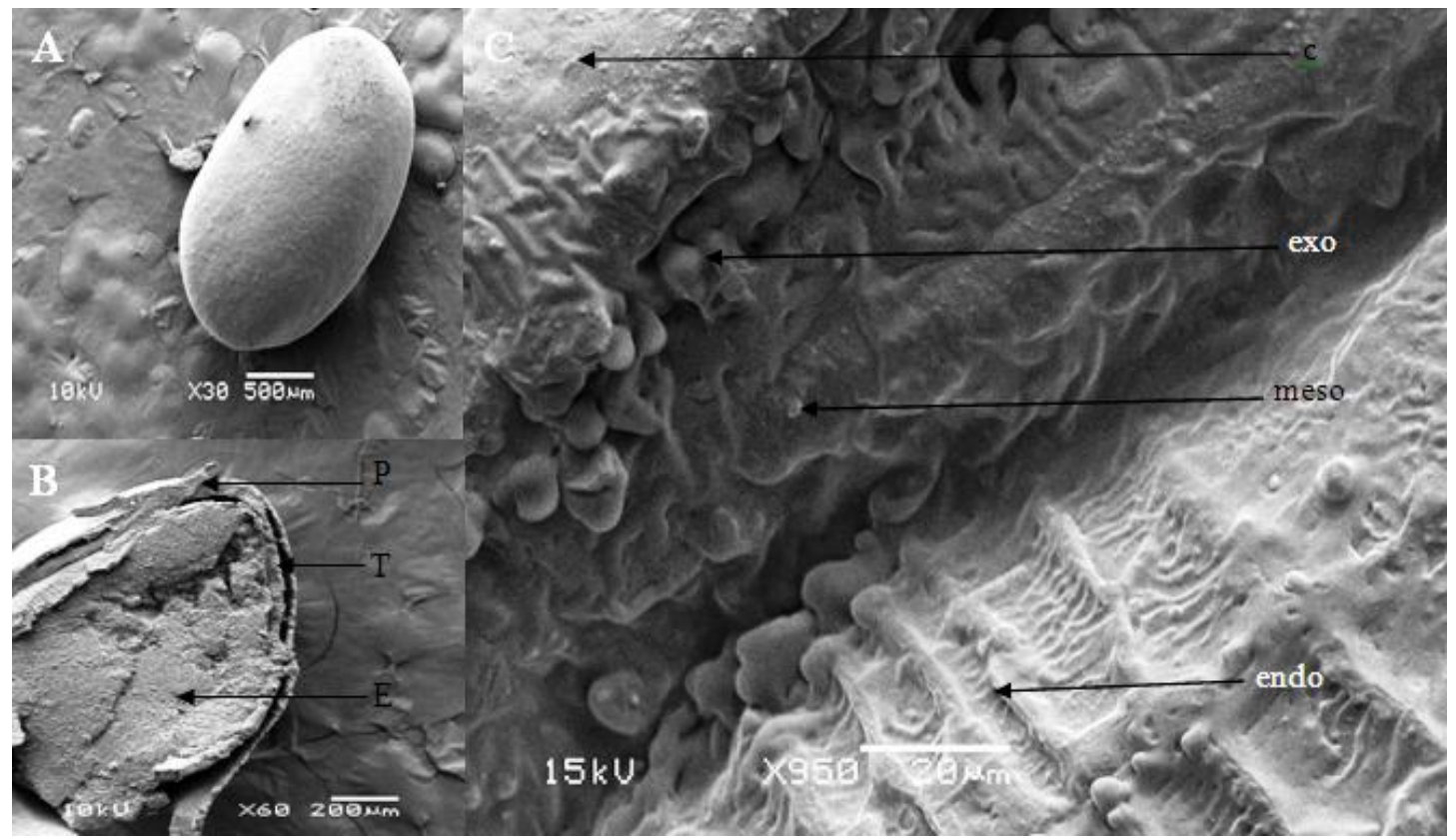

Figure 1. SEM micrograph of chia seed microstructure. A: The whole seed $(500 \mu \mathrm{m}, \mathrm{X30})$, B: Seed longitudinal section $(200 \mu \mathrm{m}, \mathrm{X60})$, and C: Pericarp longitudinal section $(20 \mu \mathrm{m}, \mathrm{X950})$

P: Pericarp; T: Testa; E: Endosperm; C: Cuticle; exo: Exocarp; meso: Mesocarp; endo: Endocarp.

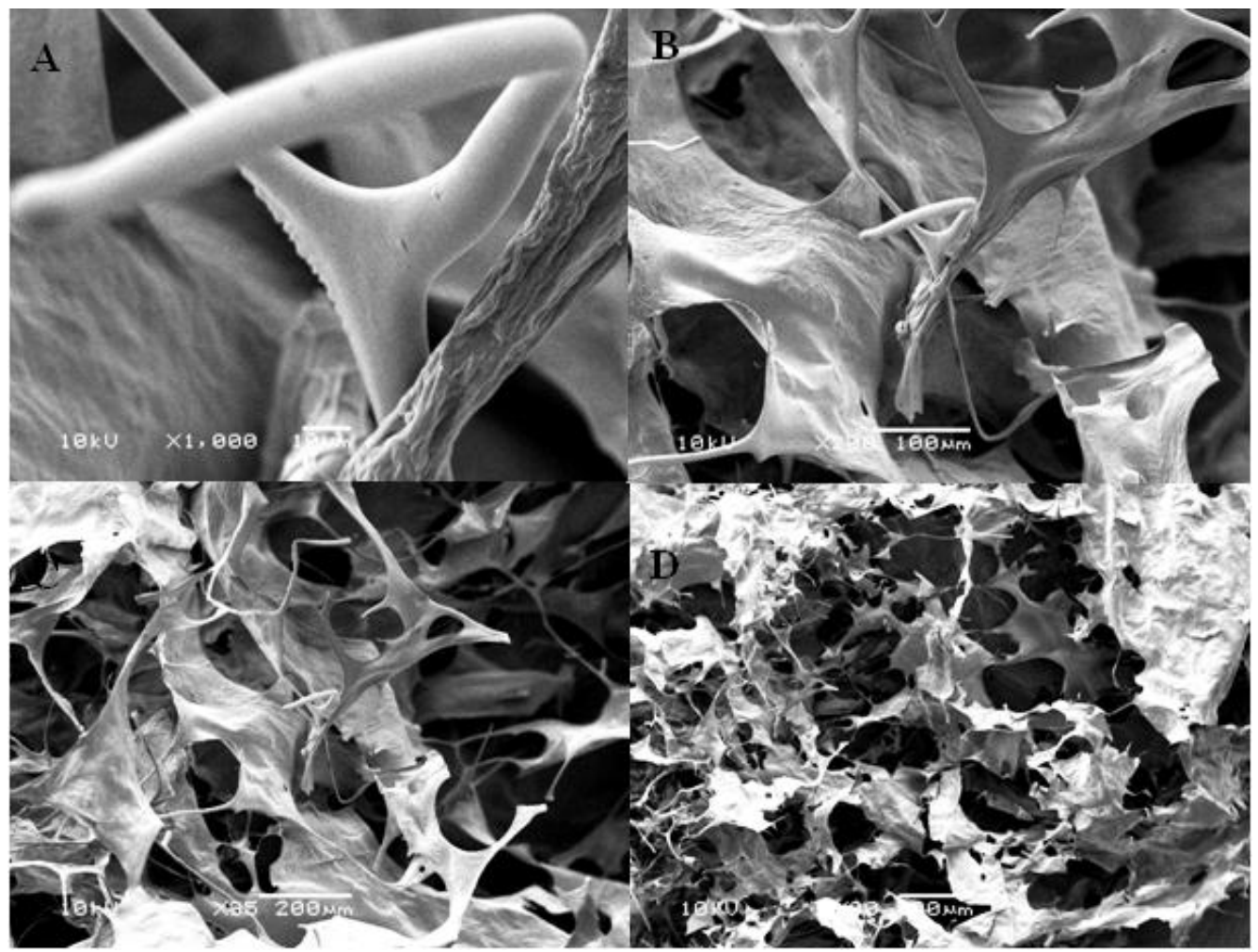

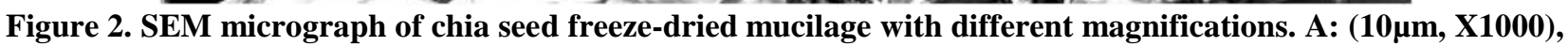
B: $(100 \mu \mathrm{m}, \mathrm{X200}), \mathrm{C}:(200 \mu \mathrm{m}, \mathrm{X85})$, and D: $(500 \mu \mathrm{m}, \mathrm{X30})$ 
are fiber, protein and fat. The chia protein related bands are shown in the transmission measurements observed at 3200 to $3500 \mathrm{~cm}^{-1}$ in all represented spectra, characterized in the broad bands at 3394, 3414 and 3402 $\mathrm{cm}^{-1}$ representing the $(\mathrm{N}-\mathrm{H})$ stretching of proteins content. Between 1739-1537 $\mathrm{cm}^{-1}$ and 1618-1915 $\mathrm{cm}^{-1}$ region for chia seeds and mucilage, respectively is used to mark the presence of amide I groups that characterize protein (Muñoz Hernández, 2012). This result supports gross chemical analysis result of protein $(12.5 \%$ Table 1). The broad band at 2872, 2933 and $2922 \mathrm{~cm}^{-1}$ is attributed to $-\mathrm{C}-\mathrm{H}$ stretching of the aromatic rings and the methyl group representing fat content (Cerqueira $e t$ al., 2011; Archana et al., 2013).

Dietary fiber of plant material in the diet which includes cellulose, non-cellulosic polysaccharides such as hemicellulose, pectin, gums, mucilage (Dhingra et al., 2012). The high fiber content of chia seeds and its mucilage were represented in more than a band group. The bands 1618-1915at $1539 \mathrm{~cm}^{-1}, 1444 \mathrm{~cm}^{-1}$, and 1419 $\mathrm{cm}^{-1}$ in case of chia seed and mucilage are assigned to the carboxyl group (-COO-) of uronic acids which agrees with the presence of uronic acid detected in chia seed polysaccharides (Pongjanyakul \& Puttipipatkhachorn, 2007). The transmission bands at $1654 \mathrm{~cm}^{-1}$ and $1618 \mathrm{~cm}^{-1}$ for chia seed and its mucilage is assigned to mannose ring (Goh et al., 2016). Additionally, the bands at $1739 \mathrm{~cm}^{-1}$ and $1157 \mathrm{~cm}^{-1}$ for chia seed, $1735 \mathrm{~cm}^{-1}$ and $1155 \mathrm{~cm}^{-1}$ for chia powder represent the $\mathrm{C}=\mathrm{O}$ and $\mathrm{C}-\mathrm{O}-\mathrm{C}$ present in the pyranose ring. The band at $1058 \mathrm{~cm}^{-1}$ in mucilage is assigned to $\mathrm{C}-\mathrm{O}-\mathrm{C}$ of $1 \rightarrow 4$ glycosidic bond ring vibration and $\mathrm{C}-\mathrm{OH}$ bending and is recognized as the characteristic of polysaccharides. Furthermore, the band at $705 \mathrm{~cm}^{-1}$ and $618 \mathrm{~cm}^{-1}$ in case of chia seeds and mucilage respectively, corresponding to the $\mathrm{CH}_{2}$ with more than 7 carbon atoms (Guillen \& Cabo, 1997), represents the $\beta$ anomeric $\mathrm{C}-\mathrm{H}$ deformation and glycosidic linkages related to glucopyranose and xylopyranose units (Kong $\& \mathrm{Yu}, 2007)$.

In summary, the FTIR features of chia seed, chia powder and its mucilage represent main functional groups indicated the preponderance of fiber and carbohydrates groups among other groups that agreed with other gums and mucilage spectra (Toğrul \& Arslan, 2003).

\section{Thermogravimetric analysis TGA}

Thermogravimetric analysis (TGA) is an accurate procedure for studying the decomposition pattern and thermal stability of food polymers. Chia mucilage was characterized in order to study its applicability in different food preparations starting from fermented milk to bakery. The TGA curve shows the sample weight loss as a function of temperature (Hosseini et al., 2013). Fig. (4a, b, and c) shows the thermal degradation behavior of whole seeds, seeds powder and freeze-dried mucilage. The weight loss was associated with three main stages for all samples. The first $\left(\sim 25-\sim 150{ }^{\circ} \mathrm{C}\right)$ is related to the evaporation of a fraction of free water contained in gum samples. Elevating temperature to $200^{\circ} \mathrm{C}$, about $10 \%$ of the mass of samples was lost. The main volatilization peak appears near $250{ }^{\circ} \mathrm{C}$. This second stage was characterized by significant higher rate of weight loss. Most of the released volatiles were mainly attributed to the degradation of the polysaccharide structure that composes the wall material to low molecular weight volatiles took place at this temperature range and a minor carbohydrate degradation (Peng et al., 2001). The weight loss resulted in the third stage approximately at $504-800{ }^{\circ} \mathrm{C}$ and $392-800{ }^{\circ} \mathrm{C}$ for chia seed and its mucilage, respectively due to slow decomposition of the solid residue from the previous step. On the other hand, analysis of TGA results demonstrated that mucilage was less thermally stable with increasing temperature than the chia seeds and powder. As the required temperature for the whole chia seed and powder to lose their half weights (T50\%) was $419.62^{\circ} \mathrm{C}$ and $405.53^{\circ} \mathrm{C}$ compared to $321.47{ }^{\circ} \mathrm{C}$ for mucilage.

However, results from TGA curves imply that chia seed (Salvia hispanica, L.), powder and its mucilage showed an excellent thermal stability and provide an opportunity to be utilized in processes that involve high temperature.

The WHC is the ability of material to retain water when subjected to centrifugal force or compression, this includes linked, hydrodynamic, and physically trapped water (Alfredo et al., 2009). Fig (5) illustrates water/ oil-holding capacity of chia mucilage compared with whole chia seeds and seeds powder.

The chia mucilage, whole chia seeds and seeds powder exhibited comparable WHC $(5.25,5,5.5 \mathrm{~g}$ water/ $\mathrm{g}$ sample, respectively). The fibrous structure that was pronounced in the microstructure of chia seeds and its mucilage was expected to augment WHC referring to Alfredo et al., (2009) results, who also suggested a physiological functional role in and blood sugar control relied on its high fiber's WHC. On the other hand, chia mucilage showed higher OHC (5.85 g oil/ g sample) than both whole seeds and powder $(3.5,2.5 \mathrm{~g}$ oil/ $\mathrm{g}$ sample) and was close to its WHC value. These results could nominate chia mucilage to perform as a stabilizer and emulsifier which previously mentioned by SalgadoCruz et al., (2013) and Suri et al., (2016). These properties could be connected to the relatively high fiber 
and protein content of chia mucilage (12.47 and $10.68 \%$ respectively) as shown in Table (1).

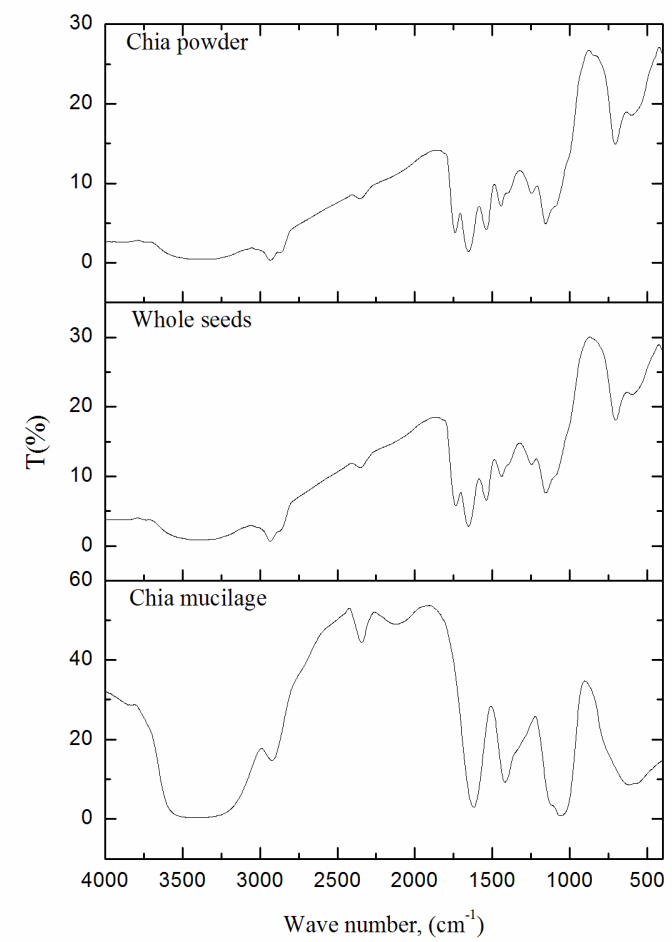

Figure 3. Fourier transform infrared spectrophotometer (FTIR) of seeds powder, whole chia seeds, and chia mucilage

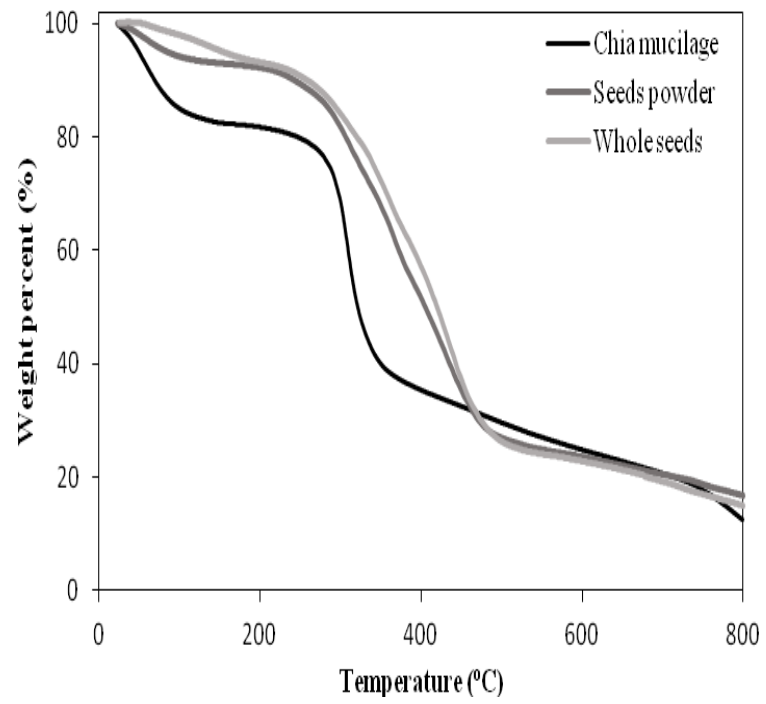

Figure 4. Thermal Gravimetric analysis (TGA) of chia mucilage, whole chia seeds, and seeds powder Water-Holding (WHC) and Oil-Holding Capacity (OHC)

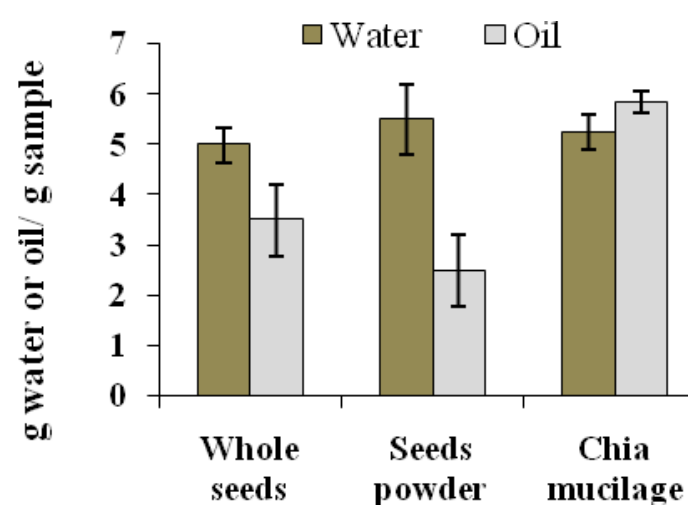

Figure 5. Water/ Oil-holding capacity of chia mucilage compared whole chia seeds and seeds powder

Gross chemical composition of chia mucilage and chia yoghurt

Gross chemical composition of chia mucilage and chia yoghurt different formulations is given in Table (1). Confirming upraised physical characterization results, chia mucilage exhibited considerable values of fiber $(12.47 \%)$, in addition to protein, ash and fat (10.68, 9.64 , and $3.10 \%$ respectively), which reflected on total solids (TS\%) content $(89.35 \%)$. These data are in agreement with Capitani et al., (2013). The collected yield was $7.24 \mathrm{~g}$ lyophilized chia mucilage/100 $\mathrm{g}$ of chia seeds, that was similar to value reported by (Felisberto et al., 2015). Although chia mucilage $\mathrm{pH}$ is acidic tends to be near neutral (6.41), fortifying with chia mucilage dispersion to yoghurt products slightly lowered products' $\mathrm{pH}$ and elevated TA\%, but these differences were insignificant. Supplementing yoghurt with chia mucilage dispersion did not significantly affect any of products' chemical parameters as compared to the control samples of each fat concentration group $(1,2$, and 3\%), except for expected significant increase in fiber content which subsequently reflected on significantly higher values of TS\%, SNF\% and F/DM\%.

\section{Texture profile analysis (TPA) of chia yoghurt}

Texture profile analysis of chia yoghurt products are given in Table (2). Comparing the hardness of the three control samples, T1, T5 and T9 $(110,103$ and 76g), revealed that hardness is inversely proportional with fat content. The same pattern was obtained when comparing amongst each control group, where softness significantly elevated directly proportional with increasing of chia mucilage concentration. Data of adhesiveness and gumminess values revealed significant descend following the same trend of hardness. On contrary, springiness showed significant increase accompanied with the increase of chia mucilage concentration. Back to springiness definition (originally called elasticity), 
Table 2. Texture profile analysis of chia yoghurt products

\begin{tabular}{lccccc}
\hline Sample & Hardness (g) & Adhesiveness (g.mm) & Cohesiveness & Springiness (mm) & Gumminess (N) \\
\hline T1 $(\mathrm{C} 1)$ & $110^{\mathrm{a}}$ & $71.32^{\mathrm{a}}$ & $0.38^{\mathrm{a}}$ & $4.86^{\mathrm{b}}$ & $42^{\mathrm{a}}$ \\
T2 & $38^{\mathrm{b}}$ & $43.07^{\mathrm{b}}$ & $0.45^{\mathrm{a}}$ & $6.38^{\mathrm{a}}$ & $17^{\mathrm{b}}$ \\
T3 & $30^{\mathrm{c}}$ & $29.32^{\mathrm{c}}$ & $0.42^{\mathrm{a}}$ & $5.87^{\mathrm{c}}$ & $13^{\mathrm{c}}$ \\
T4 & $27^{\mathrm{d}}$ & $29.21^{\mathrm{c}}$ & $0.46^{\mathrm{a}}$ & $5.47^{\mathrm{d}}$ & $12^{\mathrm{d}}$ \\
& & & & & \\
T5 (C2) & $103^{\mathrm{a}}$ & $46.97^{\mathrm{a}}$ & $0.38^{\mathrm{a}}$ & $6.35^{\mathrm{a}}$ & $39^{\mathrm{a}}$ \\
T6 & $65^{\mathrm{b}}$ & $43.24^{\mathrm{b}}$ & $0.36^{\mathrm{a}}$ & $6.52^{\mathrm{a}}$ & $23^{\mathrm{b}}$ \\
T7 & $53^{\mathrm{c}}$ & $40.86^{\mathrm{c}}$ & $0.35^{\mathrm{a}}$ & $5.75^{\mathrm{b}}$ & $19^{\mathrm{c}}$ \\
T8 & $51^{\mathrm{d}}$ & $37.03^{\mathrm{d}}$ & $0.36^{\mathrm{a}}$ & $5.93^{\mathrm{b}}$ & $18^{\mathrm{d}}$ \\
& & & & & \\
T9 (C3) & $76^{\mathrm{a}}$ & $28.56^{\mathrm{c}}$ & $0.41^{\mathrm{a}}$ & $4.90^{\mathrm{b}}$ & $31^{\mathrm{a}}$ \\
T10 & $65^{\mathrm{b}}$ & $27.09^{\mathrm{d}}$ & $0.48^{\mathrm{a}}$ & $5.94^{\mathrm{a}}$ & $31^{\mathrm{a}}$ \\
T11 & $53^{\mathrm{c}}$ & $22.15^{\mathrm{a}}$ & $0.44^{\mathrm{a}}$ & $6.32^{\mathrm{a}}$ & $23^{\mathrm{b}}$ \\
T12 & $50^{\mathrm{d}}$ & $21.46^{\mathrm{b}}$ & $0.41^{\mathrm{a}}$ & $6.16^{\mathrm{a}}$ & $21^{\mathrm{b}}$ \\
\hline
\end{tabular}

- Data are the mean of duplicates

- $\quad$ a,b,c,.. Means values in the same column (of each control group) marked with unlike letters are significantly different ( $<<0.05$ )

Table 3. Sensory evaluation of chia yoghurt products

\begin{tabular}{lclclcc}
\multirow{2}{*}{ Treatments } & \multicolumn{2}{c}{ Smell \&Taste } & \multicolumn{2}{c}{ Body \&Texture } & \multicolumn{2}{c}{ Appearance } \\
\cline { 2 - 6 } & Grade $^{\mathrm{a}}$ & Description & Grade $^{\mathrm{b}}$ & Description & Grade $^{\mathrm{a}}$ & Description \\
\hline T1 (C1) & $3.00 \pm 0.48^{\mathrm{a}}$ & Typical & $1.53 \pm 0.24^{\mathrm{a}}$ & Good & $3.00 \pm 0.63^{\mathrm{a}}$ & Good \\
T2 & $3.10 \pm 0.41^{\mathrm{a}}$ & Typical & $1.51 \pm 0.20^{\mathrm{a}}$ & Soft & $3.07 \pm 0.45^{\mathrm{a}}$ & Good \\
T3 & $3.15 \pm 0.33^{\mathrm{a}}$ & Typical & $1.51 \pm 0.18^{\mathrm{a}}$ & Soft & $3.13 \pm 0.45^{\mathrm{a}}$ & Good \\
T4 & $3.20 \pm 0.37^{\mathrm{a}}$ & Good & $1.44 \pm 0.13^{\mathrm{a}}$ & Soft & $3.15 \pm 0.37^{\mathrm{a}}$ & Good \\
& & & & & & \\
T5 (C2) & $3.02 \pm 0.35^{\mathrm{a}}$ & Good & $1.44 \pm 0.28^{\mathrm{a}}$ & Good & $2.93 \pm 0.49^{\mathrm{a}}$ & Good \\
T6 & $3.16 \pm 0.22^{\mathrm{a}}$ & Good & $1.53 \pm 0.17^{\mathrm{a}}$ & Soft & $3.04 \pm 0.19^{\mathrm{a}}$ & Good \\
T7 & $3.29 \pm 0.27^{\mathrm{a}}$ & Good & $1.59 \pm 0.21^{\mathrm{a}}$ & Soft & $3.24 \pm 0.41^{\mathrm{a}}$ & Good \\
T8 & $3.11 \pm 0.27^{\mathrm{a}}$ & Good & $1.52 \pm 0.17^{\mathrm{a}}$ & Soft & $3.00 \pm 0.40^{\mathrm{a}}$ & Good \\
& & & & & & \\
T9 (C3) & $2.78 \pm 0.38^{\mathrm{a}}$ & Fatty & $1.24 \pm 0.19^{\mathrm{a}}$ & Weak & $2.47 \pm 0.28^{\mathrm{a}}$ & Weak \\
T10 & $2.82 \pm 0.29^{\mathrm{a}}$ & Fatty & $1.37 \pm 0.19^{\mathrm{a}}$ & Soft & $2.69 \pm 0.41^{\mathrm{a}}$ & Good \\
T11 & $2.89 \pm 0.33^{\mathrm{a}}$ & Fatty & $1.33 \pm 0.24^{\mathrm{a}}$ & Soft & $2.71 \pm 0.56^{\mathrm{a}}$ & Good \\
T12 & $2.90 \pm 0.51^{\mathrm{a}}$ & acidic & $1.38 \pm 0.17^{\mathrm{a}}$ & syneresis & $2.58 \pm 0.47^{\mathrm{a}}$ & syneresis \\
\hline
\end{tabular}

Data are the mean of 10 panelists \pm SD

Grade $^{\text {a }}$ (1-4): 1: bad, 2: sufficient, 3: good, 4: very good.

Grade $^{\mathrm{b}}$ (1-2): 1: weak, 2: normal.

a,b,c,.. Means values in the same column (of each control group) marked with unlike letters are significantly different (p<0.05)

that it is the rate at that a deformed sample returns to original size and shape after the force is removed (Trinh \& Glasgow, 2012), that could be interpreted when referred to the fibrous nature of supplemented chia mucilage. On the other hand, cohesiveness (strength of internal bonds in the sample) did not significantly affect with chia mucilage supplementation. Overall TPA result indicted that yoghurt supplementation with chia mucilage dispersion, positively affected its texture to be softer and smoother with strong internal bonds thatincreased its springiness, which was connected to organoleptic evaluation when chia yoghurt described as "soft".

\section{Sensory evaluation of chia yoghurt}

Sensory evaluation of chia yoghurt products is exhibited in Table (3). Although, no significant differences were recorded, the chia mucilage positive effect was pronounced through supplemented samples that described as "soft", confirming the TPA results. Depending on obtained results of the three groups contingent on fat concentration, it is recommended to apply chia mucilage fortification to low fat yoghurt products ( $1 \%$ and $2 \%$ fat), with concentrations of $(1,1.5$ and $2 \%$ ), while supplementation to a higher fat concentration (3\%) may cause taste and texture to be ruined. 


\section{CONCLUSION}

Chia mucilage micrographs showed fine fibrous network structure supported with high fiber, protein, ash and fat values $(12.4,10.68,9.64$, and $3.10 \%$, respectively) announced in its gross chemical composition. The FTIR analysis indicated the presence of uronic acids, mannose, carboxylic acid, pyranose, glucopyranose, xylopyranose groups in the chia mucilage polysaccharides, which influenced its thermal stability behavior. On the other hand, chia mucilage showed high $\mathrm{OHC}$ value (5.85 g oil/ g sample) and was close to its WHC (5.25 g water/ g sample) that nominate it to perform as a stabilizer and emulsifier. Along with increasing of chia mucilage concentrations in fortified yoghurts, fiber content elevation subsequently reflected on significantly higher values of springiness, and descendant hardness values that produced "soft" yoghurts as described by panelists in sensory evaluation. According to obtained results, chia mucilage is recommended as food additive in food industry due to its unique structural, physical and compositional properties. This outcome would provide useful information to manufacturers contributing innovative applications of chia seed mucilage as reach natural fat mimetic, thermal stable thickening and gelling agent, in addition to the use of a "clean label" claim when marketing the product.

\section{ACKNOWLEDGEMENT}

Authors appreciate the support provided by, Food Technology Dept., Arid Lands Cultivation Research Institute (ALCRI) and Advanced Technology and New Materials Research Institute (ATNMRI), City of Scientific Research and Technological Applications (SRTA-City), Alexandria, Egypt, to achieve this work.

\section{REFERENCES}

Alfredo, V. O., R. R.Gabriel, C. G.Luis and B. A.David. 2009. Physicochemical properties of a fibrous fraction from chia (Salvia hispanica L.). LWT - Food Sci. Technol. 42: 168173 https://doi.org/10.1016/j.lwt.2008.05.012.

Ali, N. M., S. K.Yeap, W. Y.Ho, B. K.Beh, S. W.Tan and S. G.Tan. 2012. The promising future of chia, Salvia hispanica L. J. Biomed. Biotechnol. 1-9 https://doi.org/10.1155/2012/171956.

Allam, M. G. M., A. M. G.Darwish, E. H. E.Ayad, E. S.Shokery and S. M.Darwish. 2017. Lactococcus species for conventional Karish cheese conservation. LWT - Food Sci. Technol. 79: 625-631 https://doi.org/10.1016/j.lwt.2016.11.032.

AOAC. 1990. AOAC: Official Methods of Analysis. 15th ed. Association of Official Analytical Chemists. INC., Arligton, Virginia. USA.
Archana, G., K.Sabina, S.Babuskin, K.Radhakrishnan, M. A.Fayidh, P.Azhagu Saravana Babu, M.Sivarajan and M.Sukumar. 2013. Preparation and characterization of mucilage polysaccharide for biomedical applications. $\begin{array}{lll}\text { Carbohydr. } & \text { Polym. 98:89-94 }\end{array}$ https://doi.org/10.1016/j.carbpol.2013.04.062.

Avila-de la Rosa, G., J.Alvarez-Ramirez, E. J.Vernon-Carter, H. Carrillo-Navas and C.Pérez-Alonso. 2015. Viscoelasticity of chia (Salvia hispanica L.) seed mucilage dispersion in the vicinity of an oil-water interface. Food Hydrocoll. 49: 200-207 https://doi.org/10.1016/j.foodhyd.2015.03.017.

Bourne, M. C. 2002. Food Texture and Viscosity: Concept and Measurement. 2nd ed. Elsevier Science \& Technology Books.

Capitani, M. I., V. Y.Ixtaina , S. M.Nolasco and M. C.Tomás. 2013. Microstructure, chemical composition and mucilage exudation of chia (Salvia hispanica L.) nutlets from Argentina. J. Sci. Food Agric. 93: 3856-3862 https://doi.org/10.1002/jsfa.6327.

Cerqueira, M. A., B. W. S.Souza, J.Simoes, J. A.Teixeira, M. R. M.Domingues, M. A.Coimbra and A. A.Vicente. 2011. Structural and thermal characterization of galactomannans from non-conventional sources. Carbohydr. Polym. 83:179-185 https://doi.org/10.1016/j.carbpol.2010.07.036.

Dhingra, D., M. Michael, H.Rajput, and R. T. Patil. 2012. Dietary fibre in foods: A review. J. Food Sci. Technol. 49:255-266 https://doi.org/10.1007/s13197-011:0365-5.

Felisberto, F., A.Lucia, C.Rodrigues, M.Teresa, P.Silva, Y.Kil and C. Joy. 2015. Use of chia ( Salvia hispanica L .) mucilage gel to reduce fat in pound cakes. LWT- Food Sci. Technol. 63:1049-1055 https://doi.org/10.1016/j.lwt.2015.03.114.

Goh, K. K. T., L. Matia-Merino, J. H.Chiang, R.Quek, S. J. B.Soh and R. G. Lentle. 2016. The physico-chemical properties of chia seed polysaccharide and its microgel dispersion rheology. Carbohydr. Polym. 149:297-307 https://doi.org/10.1016/j.carbpol.2016.04.126.

Guillen, M. D. and N.Cabo. 1997. Infrared Spectroscopy in the Study of Edible Oils and Fats. J. Sci. Food Agric. 75, 1 https://doi.org/10.1002/(SICI)10970010(199709)75:1<1::AID-JSFA842>3.0.CO,2-R.

Hosseini, S. F., M. Zandi, M.Rezaei and F.Farahmandghavi. 2013. Two-step method for encapsulation of oregano essential oil in chitosan nanoparticles: Preparation, characterization and in vitro release study. Carbohydr. Polym. 95:50-56 https://doi.org/10.1016/j.carbpol.2013.02.031.

Hussein, M. M., F. A. M.Hassan, H. H.Abdel Daym, A. Salama, A. K.Enab and A. A.Abd El-Galil. 2011. Utilization of some plant polysaccharides for improving yoghurt consistency. Ann. Agric. Sci. 56: 97-103 https://doi.org/10.1016/j.aoas.2011.05.010. 
Khalifa, M. E. A., A. E.Elgasim, A. H.Zaghloul and M. B.Mahfouz. 2011. Application of inulin and mucilage as stabilizers in yoghurt production. Am. J. Food Technol. 6:31-39.

Kong, J. and S.Yu. 2007. Fourier transform infrared spectroscopic analysis of protein secondary structures. Acta Biochim. Biophys. Sin. (Shanghai). 39: 549-559 https://doi.org/10.1111/j.1745-7270.2007.00320.x.

Mirhosseini, H. and B. T.Amid. 2012. A review study on chemical composition and molecular structure of newly plant gum exudates and seed gums. Food Res. Int. 46:387-398

https://doi.org/10.1016/j.foodres.2011.11.017.

Munir, H., M.Shahid, F.Anjum and D. Mudgil. 2016. Structural, thermal and rheological characterization of modified Dalbergia sissoo gum-A medicinal gum. Int. J. Biol. Macromol. 84:236-245 https://doi.org/10.1016/j.ijbiomac.2015.12.001.

Muñoz, L. A., A.Cobos, O. Diaz and J. M.Aguilera. 2012. Chia seeds: Microstructure, mucilage extraction and hydration. J. Food Eng. 108:216-224 https://doi.org/10.1016/j.jfoodeng.2011.06.037.

Muñoz Hernández, L. 2012. Mucilage from chia seeds (Salvia hispanica): microestructure, physico-chemical characterization and applications in food industry.

Nikoofar, E., M.Hojjatoleslamy, A.Shakerian and H.Molavi. 2013. Surveying the Effect of Oat Beta Glucan As a Fat Replacer on Rheological and Physicochemical Characteristics of Non Fat Set Yoghurt. Int. J. Farming Allied Sci. 2: 861-865.

Oladoja, N. A., E. I.Unuabonah, O. S.AMUDA and O. M.Kolawole. 2017. Polysaccharides as a Green and Sustainable Resources for Water and Wastewater Treatment.
Peng, W., Q.Wu and P. Tu. 2001. Pyrolytic characteristics of heterotrophic Chlorella protothecoides for renewable biofuel production. J. Appl. Phycol. 13: 5-12 https://doi.org/10.1023/A:1008153831875.

Pongjanyakul, T. and S.Puttipipatkhachorn. 2007. Xanthanalginate composite gel beads: Molecular interaction and in vitro characterization. Int. J. Pharm. 331: 61-71 https://doi.org/10.1016/j.ijpharm.2006.09.011.

Salgado-Cruz, M. de la P., G.Calderón-Domínguez, J.Chanona-Pérez, R. R.Farrera-Rebollo, J. V.MéndezMéndez and M.Díaz-Ramírez. 2013. Chia (Salvia hispanica L.) seed mucilage release characterisation. A microstructural and image analysis study. Ind. Crops Prod. 51: 453-462 https://doi.org/10.1016/j.indcrop.2013.09.036.

Suri, S., S.Passi and J. Goyat. 2016. Chia Seed ( Salvia Hispanica L . ) - a New Age Functional Food.Pages 286299 in 4th International Conference on Recent Innovations in Science Engineering and Management. India International Centre, New Delhi.

Szczesniak, A. S., M. A.Brandt and H. H. Friendman. 1963. Development of Standard Rating Scales for Mechanical Parameters of Texture and Correlation Between the Objective and the Sensory Methods of Texture Evaluation. J. Food Sci. 28:397-403 https://doi.org/10.1111/j.13652621.1963.tb00217.x.

Tamime, A. Y. and R. K. Robinson. 1999. Yoghut Science and Technology. 2nd ed. Woodhead Publishing Ltd and CRC Press LLC, Cambridge, England.

Toğrul, H. and N.Arslan. 2003. Flow properties of sugar beet pulp cellulose and intrinsic viscosity-molecular weight relationship. Carbohydr. Polym. 54: 63-71 https://doi.org/10.1016/S0144-8617(03)00146-2.

Trinh, T. K. and S.Glasgow. 2012. On the texture profile analysis test. Institute of Food Nutrition and Human Health, Massey University, New Zealand. 


\section{الملخص العربي}

\section{الخصائص التركيبية والوظيفية لمستخلص بذور الشيا Salvia hispanica L.) والمستخدمة لتدعيم}

\section{الزيادي قليل الاسم}

أميرة محمد درويش، راندة خليفة، صبحي أحمد السحيمي لرئ لإسم

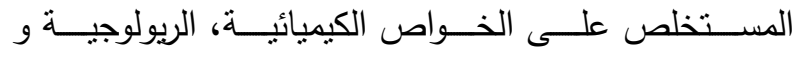
الخصائص الحسية للزبادي. أظهر الميكروجراف لمستخلص

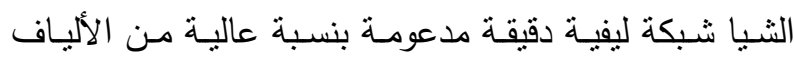

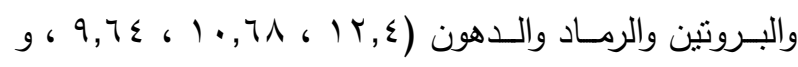

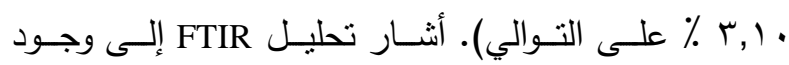

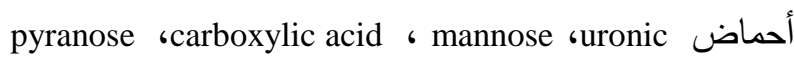
، glucopyranose ، المستخلص العديدة، والتي أثنرت على استقرارها الحراري.

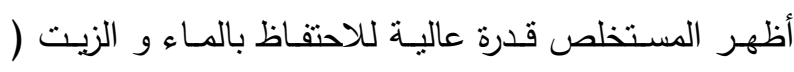

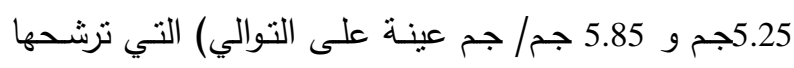

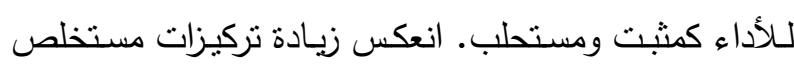

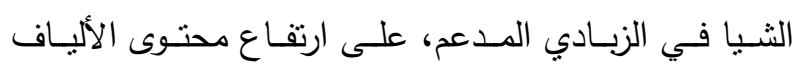

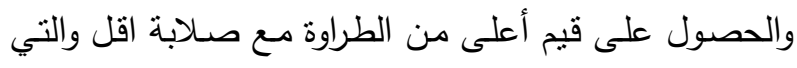

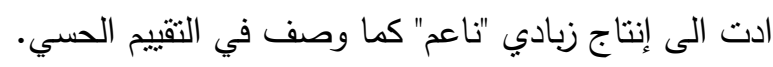

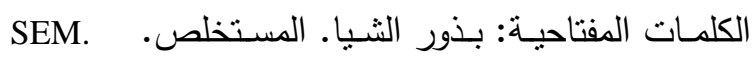
FTIR. TGA
منطلبـات الحياة الغذائية الحديثة من الأطعمـة الطبيعيـة

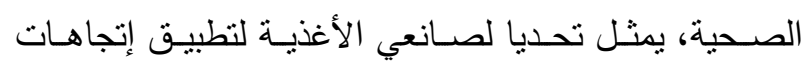

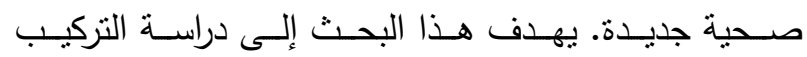
المجهري لبذرة الثيا (Salvia hispanica L.) ومستخلصها،

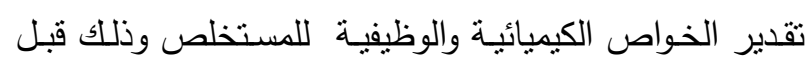

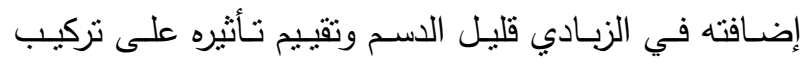

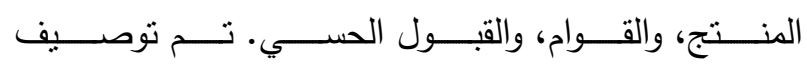

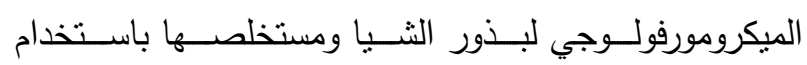

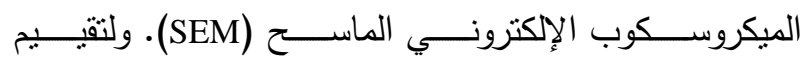

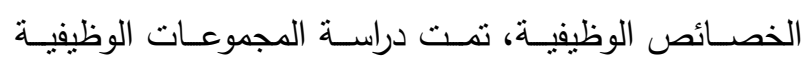

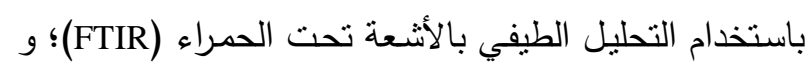
تم تحليل السلوك الحراري باستخدام محلل قياس النقل النوعي

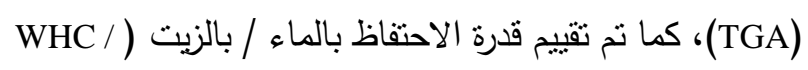

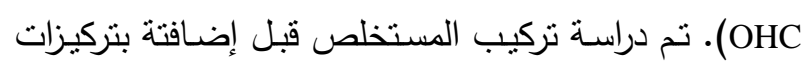
مختلفة (1 ، 1,0 و ץ \%) إلى نسب مختلفـة مـن محتوى

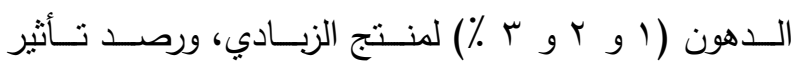

